\title{
Quantification of mRNA using real-time reverse transcription PCR (RT-PCR): trends and problems
}

\author{
S A Bustin
}

Academic Department of Surgery, Barts and the London, Queen Mary's School of Medicine and Dentistry, University of London, London E1 1BB, UK

(Requests for offprints should be addressed to S A Bustin; Email: s.a.bustin@qmul.ac.uk)

\begin{abstract}
The fluorescence-based real-time reverse transcription PCR (RT-PCR) is widely used for the quantification of steady-state mRNA levels and is a critical tool for basic research, molecular medicine and biotechnology. Assays are easy to perform, capable of high throughput, and can combine high sensitivity with reliable specificity. The technology is evolving rapidly with the introduction of new enzymes, chemistries and instrumentation. However, while real-time RT-PCR addresses many of the difficulties inherent in conventional RT-PCR, it has become increasingly clear that it engenders new problems that require urgent attention. Therefore, in addition to providing a snapshot of the state-of-the-art in real-time RT-PCR, this review has an additional aim: it will describe and discuss critically some of the problems associated with interpreting results that are numerical and lend themselves to statistical analysis, yet whose accuracy is significantly affected by reagent and operator variability.
\end{abstract}

Journal of Molecular Endocrinology (2002) 29, 23-39

\section{Introduction}

The fundamental importance of nucleic amplification methods in basic research, pharmacogenomics and molecular diagnostics (Schweitzer \& Kingsmore 2001) continues to direct efforts aimed at improving current methodologies as well as the development of novel technologies. Not all are based on target amplification: the 'Invader' assay is a development of the invasive signal amplification assay (Lyamichev et al. 1999) that combines two signal amplification reactions in series to generate and amplify a fluorescent signal in the presence of the correct target sequence (Hall et al. 2000). It is an isothermal, PGR-free assay that uses a structurespecific thermostable archaebacterial flap endonuclease (FEN) (Harrington \& Lieber 1994) which, when used in conjunction with structure-forming probes, cleaves nucleic acids at specific sites based on structure rather than sequence. Because there is no need for special post-reaction containment, these assays may be run in standard microtitre plates (Eis et al. 2001). The assay is sensitive down to sub-attomole levels and may well become a method of choice in the future.

However, for now reverse transcription (RT)PCR-based assays are the most common method for characterising or confirming gene expression patterns and comparing mRNA levels in different sample populations (Orlando et al. 1998). Despite the wide variability of results characteristic of conventional RT-PCR assays (Reinhold et al. 2001) and its unreliability as a clinical diagnostic tool (Calogero et al. 2000), considerable attention is still focused on conventional, competitive protocols (Gilliland et al. 1990) with steady improvements to internal standards, references for data normalisation as well as the introduction of new mathematical models for data analysis (Halford et al. 1999, Vu et al. 2000).

The most promising innovation applied to conventional RT-PGR protocols is the development 
of standardised, quantitative, competitive RT-PCR (Willey et al. 1998), which is also known as Standardised RT-PGR (StaRT). StaRT addresses some of the major problems associated with conventional competitive RT-PGR protocols: the use of standardised competitor templates allows comparison between experiments and the use of internal standards solves problems of variation in template starting amounts and operator loading errors (Grawford et al. 2001). The method uses standardised primer and internal competitor template sets that are tailored individually for each target gene. These amplify with the same kinetics as the target under investigation, and generate conventional RT-PCR products. Target gene mRNA levels are measured relative to their respective competitor templates and are normalised to reference genes to control for cDNA loaded into the reaction. This results in the reporting of each gene expression measurement as a numerical value that allows direct comparison between experiments carried out within the same or different laboratories. The design of the assay allows the analysis to be performed at the endpoint of the RT-PCR reaction and it can be automated through the use of capillary electrophoresis or microchannel electrophoresis instruments, such as the Agilent 2100 bioanalyser. At the moment, there are hundreds of such target/competitor sets available and all can be multiplexed in the same reaction. The intriguing aspect of this standardisation is that a common databank has been set up that will eventually allow the consolidation of individual results into what have been termed interactive gene expression indices (DeMuth et al. 1998). This system, together with the databank, has been commercialised (www.genexnat.com). The main disadvantage of the system is probably the inflexibility inherent in a system that is limited to sets of primers available from one supplier. Furthermore, it does not eliminate the errors associated with individuals carrying out the reactions.

Conceptual simplicity, practical ease (Wall \& Edwards 2002) and the promise of high throughput (Cohen et al. 2002a) have made the homogeneous real-time fluorescence detection assay (Heid et al. 1996) the most widely used mRNA quantification method for research application such as monitoring transcription in vitro (Liu et al. 2002) and direct detection of the effects of receptor signalling (Yuen et al. 2002). Its potential as a clinical diagnostic assay (Bustin \& Dorudi 1998) is also being realised, and its use has been reported for the identification of micrometastases or minimal residual disease in colorectal cancer (Bustin et al. 1999), neuroblastoma (Cheung \& Cheung 2001), prostate cancer (Gelmini et al. 2001) and leukaemia (Buonamici et al. 2002). It has been used to distinguish different types of lymphoma (Bijwaard et al. 2001), for the analysis of cellular immune responses in the peripheral blood (Hempel et al. 2002), the detection of bacterial (Goerke et al. 2001) and viral (Greijer et al. 2002) RNA in clinical samples and for monitoring the response of human cancer to drugs (Miyoshi et al. 2002). Other clinically relevant applications include its use for the detection of gene amplification in breast cancer (Bieche et al. 1999), for the analysis of tissue-specific gene expression (Bustin et al. 2000) and for cytokine mRNA profiling (Stordeur et al. 2002).

As with all new technologies, continuous improvements in enzymology, chemistry and instrumentation are taking place and a web site that encourages users to relate their real-life experiences to rate instruments, reagents and suppliers has appeared (www.biowire.com) to provide useful information for experienced users and novices alike. Undoubtedly, these developments advance the ease, and help reduce the cost, of applying this technology to the many applications suited to real-time analysis. On the other hand, the introduction of new enzymes, quenchers, peptide nucleic acids, instruments and chemistries makes it increasingly difficult to compare results obtained in different laboratories.

\section{Automation}

Although real-time RT-PCR is perceived as less labour-intensive and more high throughput than conventional RT-PGR, two bottlenecks remain: template preparation and the dispensing of reagents. The recent introduction of robotics into molecular biology promises to address both issues and should also reduce the variability and contamination observed when different operators prepare multiple templates (Mifflin et al. 2000). At the basic level, Applied Biosystems (ABI) (www. appliedbiosystems.com) have recently launched the 6100 Nucleic Acid PrepStation, a small-footprint stand-alone instrument that uses an integrated vacuum system with an application-specific 
membrane to purify RNA or DNA. It is designed to produce 96 samples in about $30 \mathrm{~min}$ but requires user supervision and intervention. One level up, Genovision (www.genovision.com) have released two fully automated robotic workstations, one processing up to 48, the other up to 96 samples using a proprietary magnetic bead system. At the top level, Roche, ABI and Qiagen have designed three robots that not only purify nucleic acids but also dispense reagents for the RT-PCR assay, and in the case of the ABI 6700 present the operator with a sealed plate that is ready to load on the thermal cycler. This eases the second bottleneck, the manual dispensing of master mixes and templates into reaction tubes, which is exceedingly tedious. Roche's (http://biochem.roche.com) Magnapure prepares RNA using proprietary magnetic particle technology and specialised reagent kits. The instrument can handle only 32 samples at any one time, which can be a limitation when not using a Lightcycler, and in our experience reproducibly produces good quality mRNA, even from difficult tissues such as colonic biopsies. ABI's 6700 automated nucleic acid workstation has the advantage of being able to process 96 samples at any one time, and is designed to be used along with ABI's real-time thermal cyclers, but is significantly more expensive. Qiagen's Biorobot 8000 (www.qiagen.com) is currently the most technically advanced robotic work station and with its eight-channel independent liquid-level sensing pipetting system can handle up to 384 samples. It uses the tried and tested RNeasy technology, together with an automated vacuum system that replaces the manual centrifugation steps.

However, in addition to substantial acquisition as well as running costs associated with these robots, we have noted some additional problems. First, the amount of biopsy sample that a robot will reliably process is limited to about $20 \mathrm{mg}$ of tissue, an issue that becomes important when the aim is to generate as much RNA as possible. It is, of course, possible to spread sample preparation over several columns, but this will result in significant cost increase. Secondly, at least in our hands, total RNA yields tend to be about half of those achieved using manual methods. Thirdly, we have had problems with the robot's mechanical reliability. However, the pace of development is such that it will not be too long before more universally affordable instruments with reliable liquid handling characteristics appear.

\section{Template preparation}

Until recently, in vivo RNA extractions and subsequent analyses were carried out from whole tissue biopsies with little regard for the different cell types contained within that sample. This inevitably results in the averaging of the expression of different cell types and the expression profile of a specific cell type may be masked, lost or ascribed to and dismissed as illegitimate transcription (Chelly et al. 1989) because of the bulk of the surrounding cells. Indeed, it is not surprising that significant differences have been detected in the gene expression profiles of microdissected and bulk tissue samples (Fink et al. 2002, Sugiyama et al. 2002). This is particularly relevant when comparing gene expression profiles between normal and cancer tissue since normal cells adjacent to a tumour may be phenotypically normal, but genotypically abnormal or exhibit altered gene expression profiles due to their proximity to the tumour (Deng et al. 1996), and some tumours have significantly larger immune cell infiltrates than others (Bustin et al. 2001). Therefore, quantitative information per se is no longer sufficient.

The introduction of laser capture microdissection (LCM) (Emmert-Buck et al. 1996) has been a crucial step forward, and in combination with microarrays and real-time RT-PCR revolutionises our ability to identify gene expression profiles. LCM allows the extraction of a pure subpopulation of cells from heterogeneous in vivo cell samples for detailed molecular analysis (Walch et al. 2001). This is done by directing a brief laser pulse at cells within a tissue section placed on a glass slide. Individual cells or groups of cells can be selected and since cells and their contents are not damaged, gene expression patterns, both at the RNA and protein levels, are maintained.

Consequently, in vivo samples subjected to quantitative RT-PCR analysis might consist of single, tens or hundreds of cells isolated during laser microdissection. Quantitative isolation of total RNA from such very small samples by traditional methods is difficult and inefficient and requires the addition of exogenous nucleic acid to the sample. For example, Qiagen recommend the addition of $20 \mathrm{ng}$ of carrier, non-polyadenylated RNA immediately after lysis and prior to loading onto the RNeasy column. However, new kits developed by Stratagene (www.stratagene.com) and Invitrogen 
(www.invitrogen.com) claim to allow the isolation of total RNA from a single cell and there are published data detailing extraction and subsequent RT-PGR assays from tens of cells (Bohle et al. 2000, Dolter \& Braman 2001).

Laser microdissection is best carried out using archival formalin-fixed paraffin-embedded tissue specimens (Lehmann et al. 2000) as such tissue is the most widely available material for retrospective clinical studies and, together with clinical data, represents an important resource for the elucidation of disease mechanisms and validation of differentially expressed genes as novel therapeutic targets or prognostic indicators. Although RNA can be extracted from such tissue (Rupp \& Locker 1988), extensive degradation can occur before (Mizuno et al. 1998) or during (Klimecki et al. 1994) the formalin fixation process. Furthermore, formalin fixation generates cross-links between nucleic acids and proteins and covalently modifies RNA, making subsequent RNA extraction, RT and quantification analysis problematic (Masuda et al. 1999). Not surprisingly, fixatives are important (Goldsworthy et al. 1999) and different tissue preparation methodologies will invariably lead to different results from different laboratories. Most guidelines for successful RT-PCR assays insist that successful quantitative RT-PCR is highly dependent on the quality of RNA. Certainly, there is evidence that cDNA yield from sequences near the $5^{\prime}$ end of partially degraded mRNAs is significantly less than from sequences near the polyA tail (Swift et al. 2000) and assays aimed at identifying RNA degradation are being developed (Sugita et al. 2001). However, it is worth remembering that real-time RT-PGR amplification generates amplicons as small as $60 \mathrm{bp}$. Therefore, this technique could be suitable for quantitating mRNA levels in tissue samples containing partially degraded RNA and might allow the analysis of quantitative changes of nucleic acids during the course of pathological alterations. Indeed, recent reports describe the isolation (Bock et al. 2001) as well as accurate and reproducible quantification of mRNA expression levels from archival paraffin-embedded tissue specimens (Godfrey et al. 2000, Specht et al. 2001, Cohen et al. 2002b), even after immunohistochemical staining (Fink et al. 2000). This is very exciting, since it may now be possible to use a single sample for immunocytochemistry, in situ hybridisation as well as quantitative RT-PCR or microarray analysis. Furthermore, Ambion (www.ambion.com) have commercialised a kit that allows reliable extraction of RNA from formalinfixed, paraffin-embedded tissue sections for use in RT-PGR, and general use of this kit should aid the process of standardisation of quantitative protocols. Finally, there can be little doubt that new preservation methods will be developed that on the one hand preserve tissue morphology while permitting the extraction of higher quality RNA than is currently possible (Parlato et al. 2002).

\section{DNase treatment}

Accurate determination of total RNA concentration is particularly important for absolute quantification of mRNA levels where mRNA copy numbers are best normalised against total RNA and any significant DNA contamination will result in inaccurate quantification. Hence, any variation in copy numbers between samples could be a reflection of different levels of DNA contamination between them. However, many researchers are reluctant to expose their precious RNA samples to DNase treatment, fearful that residual RNases will degrade it or affect its long-term storage. We routinely add DNase only to the sample to be quantitated, leaving the stock untreated. Only when forced to use a probe that is not intron-spanning do we also DNase-treat the sample to be amplified ( $\mathrm{Li}$ et al. 2000). Column-based RNA purification kits, such as those supplied by Qiagen or Strategene's Absolutely RNA, claim to allow the isolation of virtually DNA-free RNA. To identify the extent of DNA contamination in non-DNasetreated RNA samples purified using RNeasy columns (Qiagen) we determined the nucleic acid concentration of a large number of RNA samples prepared by different individuals from in vivo biopsies and tissue culture cells before and after treatment with DNase (Qiagen). The results (Fig. 1) provide conclusive evidence that there is significant contamination, with RNA constituting on average $50-80 \%$ of the purified nucleic acid. However, there is a wide range, with some preparations virtually pure RNA and others virtually pure DNA and this is tissue origin- or operator-independent.

If precious samples are to be DNase-treated, it is necessary to ensure that the DNase is removed 


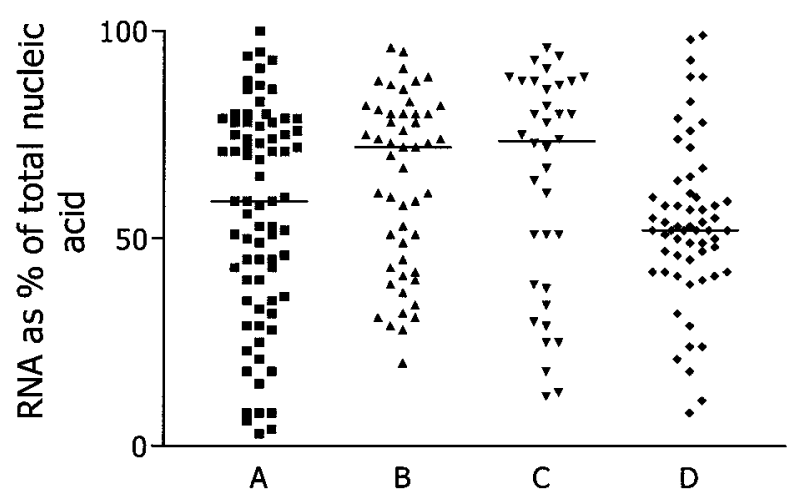

Figure 1. DNA contamination of RNeasy-purified total RNA. Standard RNeasy protocols were used to prepare total RNA from surgically resected biopsies: $(A)$ breast, $n=76$ and (B) colon, $n=51$; from biopsies obtained during sigmoidoscopy (C) $n=36$ and from HT-29 tissue culture cells (D), $n=60$. Nucleic acid concentrations of the individual samples were determined before and after treatment with RNase-free DNase. Post-treatment concentrations were expressed as percentages of the pre-treatment concentrations and plotted to show RNA as a percentage of total nucleic acid for each sample. The horizontal bar shows the median percentage RNA.

prior to any RT step. When using manual columns or fully automated RNA extraction protocols on a robot, it is most convenient, although arguably less efficient, to carry out the DNase digestion in situ. This also permits the removal of the DNase during the subsequent wash steps. For non-column-based protocols, Ambion have introduced a system called 'DNase-free' which consists of RNase-free DNase and a DNase removal reagent which binds to and removes the DNase as well as divalent cations following a centrifugation. The main drawbacks, as ever, are the additional steps involved, as well as the significant additional costs incurred, especially when treating numerous samples.

\section{RT}

The RT step is critical for sensitive and accurate quantification and the amount of cDNA produced by the reverse transcriptase must accurately represent RNA input amounts. Therefore, the dynamic range, sensitivity and specificity of the enzyme are prime considerations for a successful RT-PCR assay. Protocols using a one tube/one or two enzyme-based approach are significantly more convenient than those using two tube/two enzymebased protocols but have been reported to be less sensitive (Battaglia et al. 1998). In our hands this is reflected by a shift in the threshold cycle $\left(C_{t}\right)$ corresponding to one order of magnitude of initial template copy number. Furthermore, as the required properties are not necessarily found in a single enzyme, careful choice of appropriate enzymes is required. Consequently, it may not be possible to compare directly quantitative data from two separate experiments. Qiagen have launched an enzyme (Sensiscript) that is claimed to maximise the RT from very dilute RNA templates $(<50 \mathrm{ng}$ ). It has both a higher affinity for RNA than conventional reverse transcriptases and a specially engineered RNase $\mathrm{H}$ function that is entirely RNA/DNA hybrid dependent and leaves DNA as well as single stranded RNA intact. To test the claim, we used Sensiscript and Superscript II (GibcoBRL, Inchinnan, UK) and oligo-dT to prepare cDNA from 2.5 and $25 \mathrm{ng}$ samples of total RNA isolated from a colorectal cancer cell line. The equivalent of 0.125 and $1.25 \mathrm{ng}$ were used in qPCR assays to detect insulin-like growth factor type I receptor (IGF-IR) mRNA, which is expressed at high levels, and the growth hormone receptor (GHR), which is expressed at medium-tolow levels in the colon. We found no difference in IGF-IR $C_{\mathrm{t}}$ between the enzymes when using the equivalent of $1.25 \mathrm{ng} \mathrm{RNA}$, but there appeared to be about five times more template in the $0 \cdot 125 \mathrm{ng}$ reaction carried out by Superscript II. For GHR, a similar result was obtained. Therefore, in practice, any manufacturer's claims need to be treated cautiously and different RNA preparations are likely to give different results with the same reverse transcriptase.

RT reactions are usually carried out between $40{ }^{\circ} \mathrm{C}$ and $50{ }^{\circ} \mathrm{C}$ and at these low temperatures there can be problems with the relative nonspecificity of the RT reaction (Raja et al. 2000). This results in non-specific priming by both forward and reverse primers and is a particular problem with very low concentrations of starting template. Here such non-specific side reactions can out-compete the desired reaction and, if the genuine target concentration is sufficiently low, results in the complete inhibition of specific product amplification. G/C- or secondary structure-rich mRNA templates (Malboeuf et al. 2001) also pose problems for reverse transcriptases transcribing at 40-50 ${ }^{\circ} \mathrm{C}$. This is because such templates can cause the enzyme to stop, dissociate from the RNA 
template, or skip over looped-out regions of RNA. Invitrogen's new avian RNase $\mathrm{H}^{-}$thermostable reverse transcriptase (Thermoscript) maintains its activity up to $70^{\circ} \mathrm{C}$, thus permitting increased specificity and efficiency of priming. However, this enzyme may be less robust than more conventional ones as it appears to be more sensitive to inhibitors present in RNA samples.

\section{PCR}

Competing side reactions such as mispriming and primer dimerisation can significantly affect the sensitivity of the PCR reaction (Chou et al. 1992). Hence there has been a clear trend towards the use of thermostable polymerases that require heat activation prior to the PCR reaction. Such modified, heat-activatable enzymes provide more specific hot start PCR conditions and can result in increased yield of specific product. Alternatively, it is possible to omit the heat activation step and add additional cycles. This results in slow activation of the enzyme (time-release) during the first ten or so cycles, which may improve specificity (KebelmannBetzing et al. 1998). Hot start enzymes are available from all major suppliers and despite their claims, there is probably little difference in the real-life performance of these enzymes.

RT-PCR assays that use Tth polymerase to reverse transcribe and carry out the PCR reaction using one enzyme/one tube protocols do not have this advantage. Indeed, as there has been no further development of the one enzyme/one tube assay format it may be time to abandon this protocol and switch to a two enzyme/one tube or two enzyme/two tube format. The main consideration here is to choose an opportune moment, since the quantitative data generated using the new protocol will not be comparable to those obtained previously.

With the significant costs associated with carrying out real-time RT-PCR reactions it is encouraging to see that several manufacturers are developing kits that can be used on the various types of real-time cyclers, including the ABI systems that are optimised for use with an internal reference dye (ROX). For example, Qiagen have launched an SYBR Green RT-PCR kit and undoubtedly will soon provide kits for hybridisation/hydrolysis assays as well. Similarly, Stratagene have developed core kits that are not tied to any one real-time cycler system. Finally, it is of course perfectly possible to prepare one's own master mixes and a good source of information about any issues to do with real-time RT-PGR issues is the ABI-independent bulletin board at qpcrlistserver@yahoogroups.com. Most of the comments are very helpful and researchers from the various manufacturers and suppliers give regular and sound advice.

\section{New technologies}

Current real-time chemistries use separate PCR primers and probes, and the generation of a fluorescent signal depends on intermolecular interactions between template, primers and probes. Sensitivity and reproducibility are broadly comparable (Hein et al. 2001), and hydrolysis and hybridisation probes, together with Molecular Beacons, are coexisting happily, with the most widespread protocols still utilising the $5^{\prime}$-nuclease assay using hydrolysis probes. However, the desire to speed up the assay is leading to continuous innovation and a new technology has appeared recently that incorporates many of the advantages of the three established technologies, but avoids their drawbacks. Scorpions (www.dxsgenotyping. com) convert sequence-specific priming and probing into a unimolecular event, making the signalling reaction extremely fast (Whitcombe et al. 1999) compared with the slower Taqman reaction, where a fluorescent signal is not generated until the polymerase has hydrolysed the dual-labelled probe. The original Scorpion consists of a specific probe sequence held in a hairpin loop configuration by complementary stem sequences on the $5^{\prime}$ and $3^{\prime}$ sides of the probe, which is complementary to the extension product of the primer (Fig. 2A). A fluorophore is attached to its $5^{\prime}$ end and is quenched in the hairpin loop configuration by a moiety joined to the $3^{\prime}$ end. This is linked to the $5^{\prime}$ end of a specific primer via a non-amplifiable monomer, typically hexethylene glycol. This prevents copying of the stem/loop and probe sequences during the polymerisation step of the PGR reaction which would lead to the opening of the hairpin loop in the absence of specific target sequences. After extension of the Scorpion primer, the specific probe sequence is able to bind to its complement within the same strand of DNA. This hybridisation event opens the hairpin loop so 


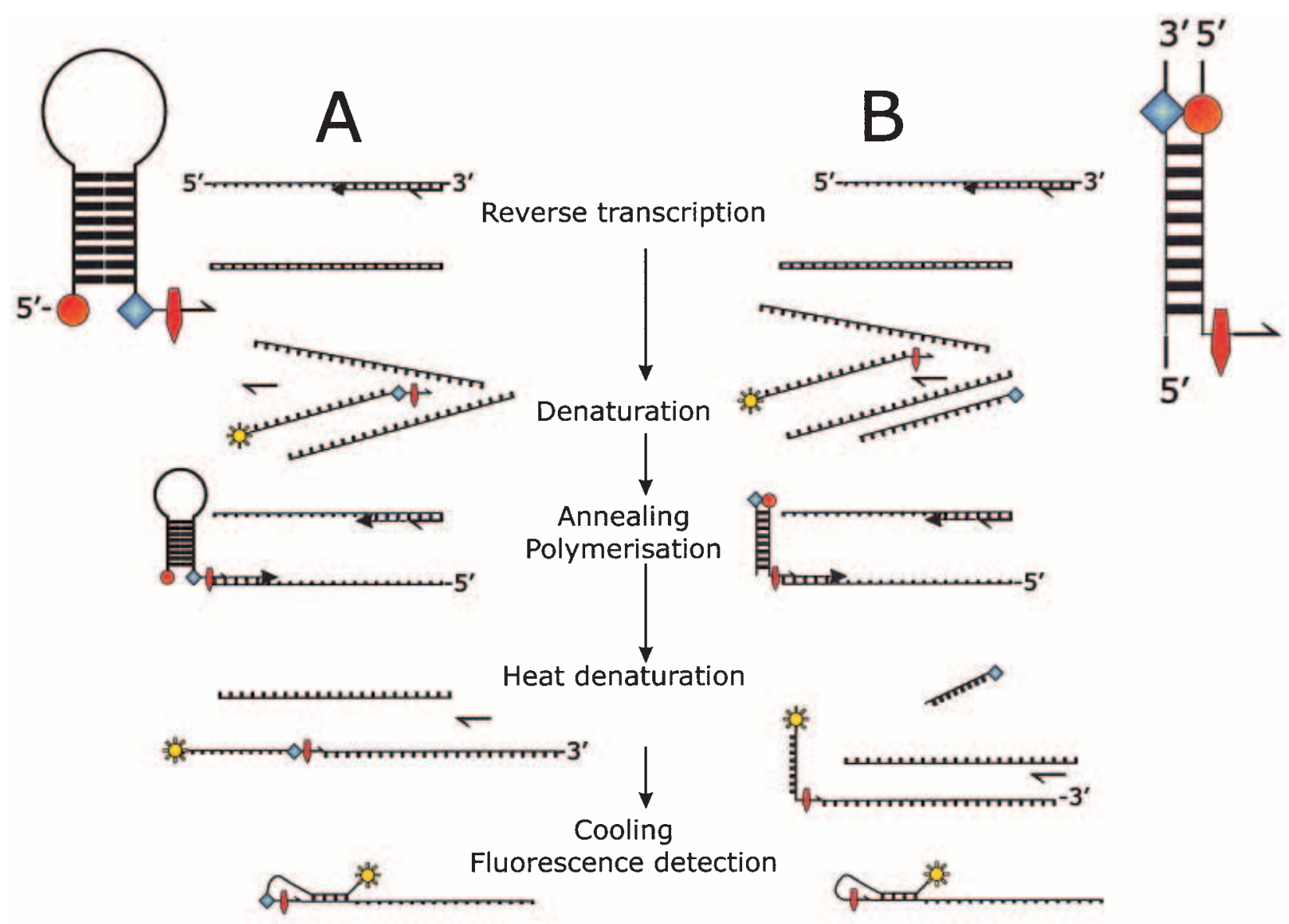

\section{Quencher $\bigcirc$ Fluorophore $\bigcirc$}

Figure 2. Real-time RT-PCR with Scorpions. A standard RT step is followed by denaturation of the double-stranded template. (A) In the hairpin loop structure, the fluorophore attached at the $5^{\prime}$ end forms a non-fluorescent complex with the quencher at the $3^{\prime}$ end. The hairpin loop is linked to the $5^{\prime}$ end of a specific primer through a PCR stopper that prevents read-through of the hairpin loop. During PCR, the Scorpion primers are extended to become part of the amplicon. During the annealing/extension phase of the PCR reaction, the probe sequence in the Scorpion hybridises to the newly formed complementary target sequence in the PCR product separating the fluorophore from the quencher and resulting in a fluorescent signal. As the tail of the Scorpion and the PCR product are now part of the same strand of DNA, the interaction is intramolecular. The target sequence is typically chosen to be within three bases of the $3^{\prime}$ end of the Scorpion primer. (B) Separation of fluorophore and quencher onto different oligonucleotides improves signal intensity. The quencher oligonucleotide has the quencher at its $3^{\prime}$ end and is complementary to the probe sequence. Following denaturation and polymerisation, intramolecular interaction of probe and newly synthesised product is more favourable than intermolecular binding between quencher oligonucleotide and the probe.

that fluorescence is no longer quenched and a fluorescent signal is observed. Unimolecular hybridisation is kinetically more favourable as it does not depend on a chance meeting between the probe, present at relatively low concentration, and the amplicon. This allows the introduction of more rapid cycling conditions together with a signifi- cantly stronger signal strength compared with both Taqman and molecular beacons (Thelwell et al. 2000). Another advantage over Taqman assays is that the PCR reaction is carried out at the optimal temperature for the polymerase, rather than at the reduced temperature required for the $5^{\prime}$-nuclease assay to displace and cleave the probe. In a 
standard Scorpion assay some quenching can occur even in the open form, since the quencher is always in the proximity of the fluorophore. Therefore, a modification, duplex scorpions, has been developed that separates the fluorophore and the quencher onto different oligonucleotides (Fig. 2B). The specific primer, PCR stopper, probe and fluorophore make up one oligonucleotide, while the quencher is linked to the $3^{\prime}$ end of an oligonucleotide that is fully complementary to the probe sequence. Since this arrangement retains the intramolecular probing mechanism, it is favoured over quencher oligonucleotide re-annealing with the Scorpion and results in better signal intensity than the normal Scorpion format. It also compares favourably with the high signal/high background ratio of the Taqman and low signal/low background ratio of molecular beacons. An additional advantage of the modified Scorpion is that it is easier to design and synthesise, as there is no hairpin loop structure and only the fluorescent dye need be attached.

The design of Scorpions requires consideration of secondary structure as well as primary sequence since it is crucial that another secondary event will not out compete the correct probing event. The use of secondary structure programs (e.g. http://bioinfo. math.rpi.edu/ mfold/dna/form l.cgi) helps, and it is likely that programs tailored to optimise Scorpion design will appear in the near future.

\section{Quenchers}

Quenchers accept energy from a fluorophore and dissipate it by one of two mechanisms. With Molecular Beacons and Scorpion primer/probes quenching is proximal due to the close contact between fluorophore and quencher and the energy is dissipated as heat (collisional quenching). With hydrolysis probes, fluorophore and quencher may be separated by up to $40 \mathrm{bp}$ and quenching is achieved by fluorescence resonance energy transfer (FRET) where the fluorophore donor transfers its energy to the quencher acceptor, which releases the energy as light of a higher wavelength. However, because FRET is distance-dependent, it is important to design dual label probes to be as short as possible. Until recently, quenchers, usually DABCYL and TAMRA, suffered from a number of drawbacks, including either poor spectral overlap between the fluorescent dye and quencher molecule (DABCYL) or inherent fluorescence of the quencher (TAMRA), resulting in a relatively poor signal-to-noise ratio. A new class of quenchers that have no native fluorescence has become available (e.g. Black Hole Quenchers (BHQ), Biosearch Technologies, Novato, CA, USA (www.biosearchtech.com/bhq)). Unlike DABCYL, which has an absorption maximum of $474 \mathrm{~nm}$, they can quench fluorescence over the entire visible spectrum and into the infrared. Thus, the BHQs more efficiently quench the most commonly used fluorescent dyes, e.g. FAM (absorption maximum $518 \mathrm{~nm})$, TET (538 nm) and Cy5 (667 nm). Another theoretical advantage is that because the BHQ probes do not themselves fluoresce, it is possible to pick multiple fluorochrome/quencher pairs and quantify several amplification reactions in the same test tube. We have compared the signals generated by two identical probes, one labelled with FAM and TAMRA, the other with FAM and a BHQ in a RT-PCR reaction designed to detect insulin-like growth factor II (IGF-II) mRNA levels in colonic biopsies. In our hands the TAMRAlabelled probe performed better, both in terms of reproducibility as well as sensitivity, with a normal colonic biopsy generating $C_{\mathrm{t}} \mathrm{s}$ of $26 \cdot 2 \pm 0 \cdot 2$ (TAMRA) and $31 \cdot 1 \pm 0 \cdot 7$ (BHQ) and the paired tumour $21 \cdot 1 \pm 0 \cdot 25$ (TAMRA) and $23 \cdot 6 \pm 0 \cdot 7$ (BHQ). I do not know whether this is due to our inexperience with BHQ probes or whether this might be specific to the IGF-II amplicon.

\section{Primers and probes}

Several new web sites assisting in the design of oligonucleotide primers and probes have appeared and the ones listed here are just a selection of the most useful ones. An online melting temperature $\left(T_{\mathrm{m}}\right)$ calculator (http://www.operon.com/oligos/ toolkit.php) provides an immediate price for the queried oligonucleotide. A nice touch is that the program also displays the complement to the oligonucleotide, plots the sequence against itself and can compare its sequence against another oligonucleotide. http://www-genome.wi.mit.edu/ cgi-bin/primer/primer3_www.cgi is a link to Primer3 primer design software and can be used to select probe sequences. It does not consider 
secondary structure issues that are relevant in primer/probe design for real-time PCR, especially molecular beacons and Scorpions. The JaMBW primer design web site (http://members.aol.com/ _ht_a/lucatoldo/myhomepage/JaMBW) is very useful for selecting appropriate primers but not probes; however some of its functionality is limited to Netscape browsers. http://www.ncbi.nlm.nih. gov/BLAST/ is the site for the Basic Local Alignment Search Tool from the National Center for Biotechnology Information and is an essential site for checking specificity of probe and primer sequences. A commercial program to assist with the design of Molecular Beacons is also available (http://www.premierbiosoft.com/molecular_beacons/ molecular_beacons.html) which could be useful when designing Beacons for multiplex reactions. Finally, it is worth emphasising that fluorescent dyes are light sensitive and therefore subject to photo bleaching. Therefore, we keep the probes in the dark until the very last moment and they are the last component we add to our reaction mixtures.

\section{Peptide nucleic acids}

Peptide nucleic acid (PNA) oligomers are analogues of DNA in which the phosphate backbone is replaced with repeating $\mathrm{N}$-(2-aminoethyl)-glycine units linked by peptide bonds (Nielsen et al. 1991). Their unique properties enable the development of assay formats that extend the possibilities of DNA probes (Stender et al. 2002). They cannot function as primers for DNA polymerase (Orum et al. 1993), but make very useful probes for real-time RT-PCR assays (Ortiz et al. 1998, Fiandaca et al. 2001). The PNA backbone is not charged and no salt is necessary to facilitate and stabilise the formation of PNA and DNA or RNA duplexes. Therefore, the $T_{\mathrm{m}}$ of a PNA/DNA duplex is significantly higher than that of a DNA/DNA duplex and is almost independent of ionic strength. When used at low ionic strength PNA will bind effectively to a target under low salt conditions in the presence of a competing DNA strand (Egholm et al. 1993). Since low salt conditions also destabilise intramolecular interactions of RNA molecules, these conditions favour hybridisation of the PNA molecule. PNAs are also useful when attempting to maximise the specificity of a probe, e.g. for the detection of mutations in DNA, as a single PNA/DNA mismatch reduces the $T_{m}$ by an average of $15^{\circ} \mathrm{C}$, compared with $11^{\circ} \mathrm{C}$ in a DNA/DNA duplex.

The higher $T_{\mathrm{m}}$ of PNA allows the use of shorter probes, but makes it important to consider the specificity of the probes to achieve a balance between the two. While a 15-mer PNA probe will have roughly the same melting temperature as a standard 25-mer, it will not have its specificity. It is probably best to aim for a PNA probe length of around 18 bases, since longer probes tend to aggregate, a problem also associated with purinerich PNA probes. A web site is available to assist with PNA probe design (http://www.bostonprobes. com/pages/science/tech-support/sci_probedesigner. html).

\section{Minor groove binding probes}

Minor groove binders (MGBs) such as dihydrocyclopyrroloindole bind to the minor groove of DNA with high affinity. When such MGBs are conjugated with oligodeoxynucleotides, the conjugates form very stable hybrids with complementary DNA (Kumar et al. 1998). Commercial MGB probes have the MGB at their $3^{\prime}$ end, since they are easier to synthesise but the MGB can be placed either at the $5^{\prime}$ or $3^{\prime}$ ends (Afonina et al. 1996). Fluorescence quenching is more efficient, giving increased sensitivity (Kutyavin et al. 2000) and the higher melting temperatures $\left(T_{\mathrm{m}}\right)$ allows the design of significantly shorter probes that are also more specific, especially if there is a mismatch in the MGB region of the duplex. MGB probes allow the design of efficient probes for $\mathrm{A} / \mathrm{T}$ rich regions of the genome and have been used successfully for single nucleotide polymorphism (SNP) analysis (Walburger et al. 2001). One problem with these probes is that the additional restrictions on where the probes can bind may make it even more difficult to find optimal probes around, for example, splice junctions. On the other hand, the shorter length of the probe compensates for this. When designing MGB probes, it is important to remember that because of the asymmetric placement of the minor groove binder at the $3^{\prime}$ end, complementary MGB probes do not necessarily have the same $\mathcal{T}_{\mathrm{m}}$. Primer Express software has been updated to allow the design of these modified 
probes (version 1.5). This version should also have removed some of the inconsistencies inherent in version $1 \cdot 0$, although it may have introduced novel bugs. Hence numerous users, including the author, continue to use version $1 \cdot 0$, forsaking the ability to design MGB probes for the security of a design setup that, whilst cumbersome, does generate primer/probe sets that work most of the time.

\section{Instrumentation}

Technology has advanced rapidly in the last 2 years and the latest real-time thermal cyclers have been developed with multiplexing and high throughput applications in mind. All aim to minimise the variability inherent in conventional RT-PCR, and monitor fluorescent signals as they are generated, recording a threshold cycle where fluorescence rises above the background but before the reaction reaches a plateau. They also seek to address the problem of cost and are designed to use less reagent and sample. Established instruments such as the Roche Lightcycler (http://biochem.roche.com/ lightcycler) and Biorad iCycler (www.biorad. com), instruments from new manufacturers, the Mx4000 (www.stratagene.com), the Smartcycler (www.smartcycler.com), the Rotor Gene 2000 (www.corbettresearch.com) and new instruments from established manufacturers, the laser-based high throughput 384-sample $7900 \mathrm{HT}$ and the halogen-based 96-sample 7000 (all from www. appliedbiosystems.com), the Chimaera Quantitative PCR System (www.thermohybaid.com) and the curiously named DNA Engine Opticon Continuous Fluorescence Detection System from MJ Research (www.mjr.com/html/instruments/opticon), compete with each other and make choosing a suitable instrument very difficult. They are all true 'realtime' systems in that progress can be monitored at any time during thermal cycling, rather than having to wait until the end of the run. This permits extension or termination of runs at will, depending on the experimental conditions. All probably perform qRT-PCR assays satisfactorily but they differ substantially on price, the user-friendliness of their software and their flexibility. Importantly, ABI does not officially support any chemistries other than the 5'-nuclease assay. Instruments relying on single excitation lasers such as the ABI 7700 and $7900 \mathrm{HT}$ tend to be the least flexible, since their laser excitation range (488-514 nm) is too narrow to excite efficiently the wide range of fluorophores available today. In contrast, halogen lamp excitation, although less intense than a laser at its maximum wavelength, provides uniform excitation over a much broader range of wavelengths. This is particularly important when considering multiplex reactions that require a choice of spectrally well-resolved fluorophores to minimise cross-talk. On the other hand, lasers offer high spectral brightness and sensitivity for fluorophores at their central wavelength. The (relatively) low price of the Roche Lightcycler and Biorad iCycler makes them very attractive for individual laboratories, although the glass capillary-based design of the Lightcycler might not suit everyone. To anyone used to the ABI 7700 , the granddaddy of real-time instruments, both are amazingly compact. The iCycler in particular is a very impressive instrument. It uses a tungsten halogen lamp, which with appropriate filters allows fluorophore excitation from 400 to $700 \mathrm{~nm}$. It can amplify 96 samples at any one time with a recently launched module extending this to 384 samples, and its operational and programming specifications certainly match those of the ABI 7700. It has also been my experience that BioRad's technical support staff are well informed and keen to help. The Rotor Gene 2000 uses four separate LED light sources that excite at 470, 530, 585 and $625 \mathrm{~nm}$. Excitation is detected using six filters and photomultipliers at 510, 555, 610, 660, 580 and $610 \mathrm{~nm}$. This instrument utilises a design that is radically different to all other instruments: the real-time reactions are carried out in standard microfuge tubes inside a 36- or 72-well rotor that spins at 500 r.p.m. This is meant to remove any temperature equilibration time and non-uniformity and sample-to-sample variation of $<0.01{ }^{\circ} \mathrm{C}$ is claimed. The Chimaera Quantitative PCR System uses a more conventional 96-well plate format on a Peltier driven thermal cycler. A halogen lamp with up to eight filters results in an excitation range of $385 \mathrm{~nm}$ to $690 \mathrm{~nm}$ with eight filters and photomultipliers detecting emissions between $430 \mathrm{~nm}$ to $800 \mathrm{~nm}$.

The recent introduction of the Stratagene Mx4000 has generated considerable interest, mainly due to the specification of the instrument, as well as the exceptional user-friendliness of the accompanying software. This cycler also uses a tungsten halogen lamp, with an excitation range 
from 350 to $750 \mathrm{~nm}$ and four photomultiplier tubes with a detection range from 350 to $830 \mathrm{~nm}$. Uniquely, it contains an integrated personal computer that operates independently from the instrument's embedded microprocessor, which affords some protection against data loss. This instrument has been designed very much with multiplexing in mind and each of the four scanning fibre-optic heads independently excites and detects dyes, reading up to four dyes in a single tube. Its excitation and emission filters are slightly offset from the peak excitation and emission wavelengths of the matched fluorophore. This offset aides in limiting leakage of fluorescence from adjacent dyes, thereby minimising background and cross-talk while enhancing dye discrimination. The thermal cycler itself is a hybrid consisting of Peltier, resistive and convective technologies that are claimed to result in improved temperature uniformity across the whole plate and reduced over- or undershooting of set temperatures. Its major disadvantage is its high price but its customer service is, in my experience, second to none.

ABI have recently introduced the relatively inexpensive ABI Prisms 7000, probably as a replacement for the 7700 . It retains the Peltierbased 96-well block thermal cycling format, but replaces the laser with a tungsten-halogen lamp that simultaneously illuminates all sample wells. Fluorescence emission is directed sequentially through four optical filters positioned on a filter wheel to a cooled, charge-coupled device (CCD) camera. In addition, ABI have listened to their users and the software supplied with the instrument is significantly enhanced compared with the limited functionality and relatively user-unfriendly software supplied with the 7700. It is also Microsoft Windows-based, which allows easy export of raw data, amplification plots, etc. for the majority of users that use this operating system. Another advantage of this system is its compact size and (relatively) reasonable price, which makes it ideal for use in individual labs. Cepheid have taken a different, but interesting approach with the design of their Smartcycler. It contains independently controlled reaction sites that allow up to 16 different reactions with different heating/cooling protocols to be run simultaneously on the same instrument. It remains to be seen whether this ability to run the same experiment under various reaction conditions simultaneously is really useful
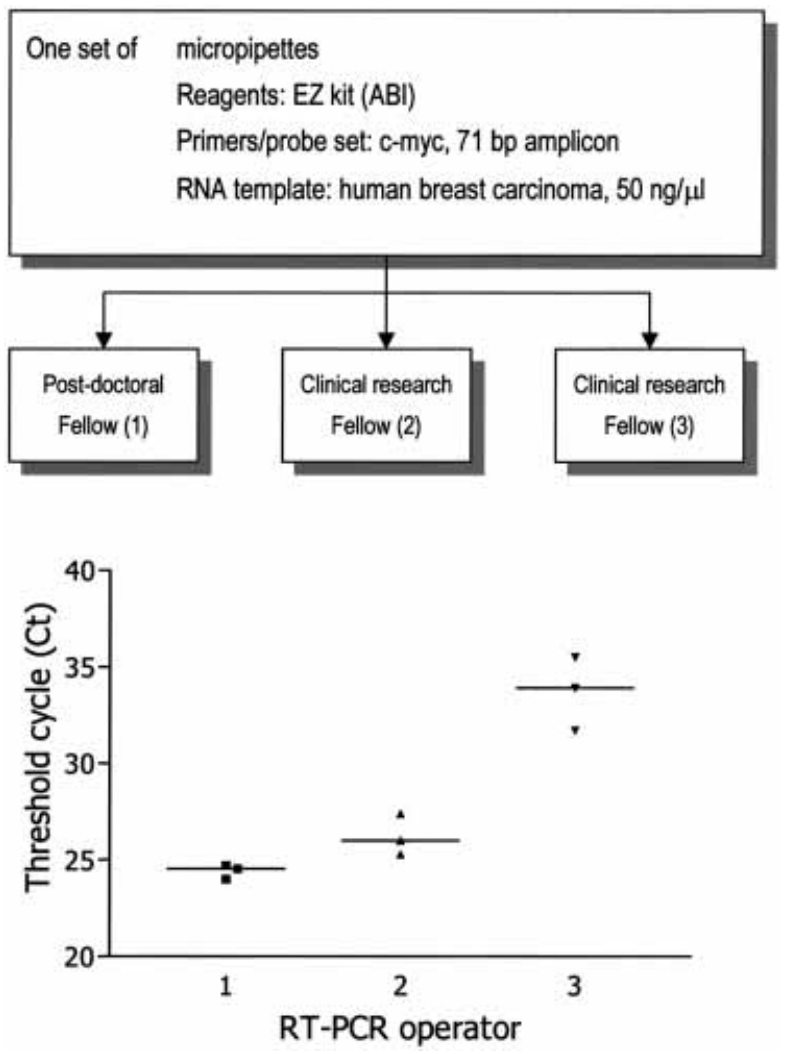

Figure 3. Operator variability. Three researchers used identical micropipettes, master mix and template to quantitate the same target on an ABI Prism 7700. Individual 1 was an experienced researcher, whereas individuals 2 and 3 were non-experts who had limited experience with dispensing reagents. The scatterplot shows the replicate $C_{t} s$ obtained by the three individuals. These translate into significantly different copy numbers $/ \mu \mathrm{g}$ total RNA of $8.7 \times 10^{5}, 2.8 \times 10^{5}$ and $2.7 \times 10^{3}$ respectively.

or whether it might increase the likelihood of operator error.

\section{Operator and reagents - sources of variability}

The variability of RT-PGR results obtained from identical samples assayed in different laboratories continues to be a problem (Bolufer et al. 2001). In real-time RT-PCR, the single most likely source of data variation is likely to be due to variability introduced by the person carrying out the experiment. Since there are so many steps involved in going from a tissue sample to a 'quantitative' result, it is not surprising that this is so. Figure 3 demonstrates the degree of variation possible 
within a single laboratory and the results provide a convincing argument for the use of robots when reproducibility and inter-laboratory comparability are the main concerns. One of the reasons for using manufacturers' kits rather than making up homemade master mixes is the expectation of lot-to-lot consistency. We investigated this by comparing the $C_{\mathrm{t}} \mathrm{s}$ obtained using a single template and two batches of ABI's EZ system, which is a oneenzyme/one-tube RT-PGR kit for the 5 '-nuclease assay. We observed significant differences in $C_{\mathrm{t}} \mathrm{s}$ that translated into a $2 \cdot 5$-fold difference in median mRNA copy numbers (Fig. 4A). We also looked at the stability of the Taqman probes and found that two lots of probe synthesised within 6 months of one another generated significant differences in $C_{\mathrm{t}}$ that resulted in a sevenfold difference in calculated mRNA copy numbers (Fig. 4B). We have also found that probes synthesised by different manufacturers have different stability upon storage, with the most consistent probes being those obtained from ABI. Hence it is important that a standard, either in the form of an oligonucleotide standard curve or a standard RNA preparation, must be included with every RT-PCR run, especially when a fresh batch of RT-PGR kit or probe is used.

\section{Normalisation}

The identification of a valid reference for data normalisation remains the most stubborn of problems and none of the solutions proposed are ideal. It is especially difficult when dealing with in vivo samples and comparing gene expression patterns between different individuals. Surprisingly, glyceraldehyde-3-phosphate dehydrogenase (GAPDH) continues to be utilised as a normaliser despite continuing reports that emphasise the problems associated with its use (Ke et al. 2000, Suzuki et al. 2000). It is now well documented that GAPDH mRNA levels are not constant (Zhu et al. 2001), that it contributes to diverse cellular functions such as nuclear RNA export, DNA replication, DNA repair, exocytotic membrane fusion, cytoskeletal organisation and phosphotransferase activity (Sirover 1999). It is pathologically implicated in apoptosis and neurodegenerative disease (Tatton et al. 2000) and its mRNA levels are highly heterogeneous even in cellular subpopulations of the same pathological origin (Goidin et al. 2001). There are some instances when

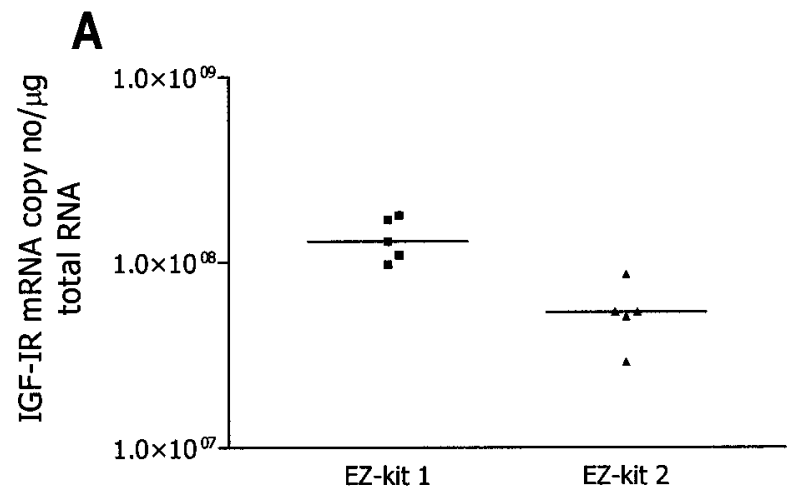

B

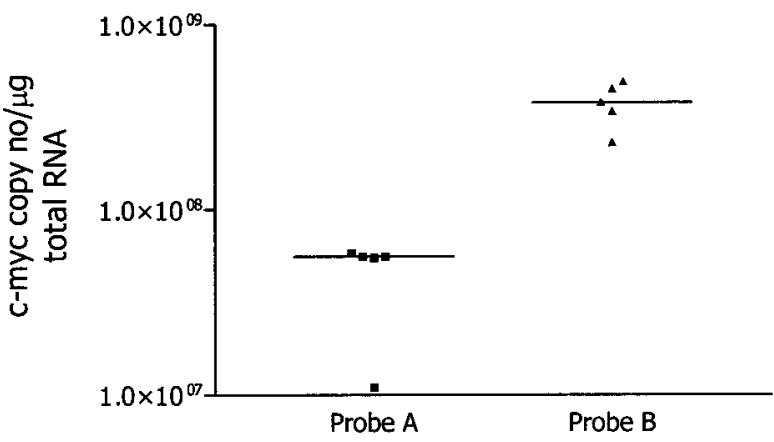

Figure 4. Effects of reagents on accuracy of quantification. (A) IGF-IR mRNA levels were determined in the same RNA sample using different lots of ABI' $E Z$ kit. Reactions were carried out a total of five times by the same individual, and the scatterplot shows the calculated individual and median mRNA copy numbers (Kit 1: $1.3 \times 10^{8} \pm 3.2 \times 10^{7}$; Kit 2: $5.4 \times 10^{7} \pm 1.6 \times 10^{7}$ copies/ $\mu \mathrm{g}$ total RNA). (B) c-myc mRNA levels were determined in the same RNA sample with two batches of probe, one stored at $+4^{\circ} \mathrm{C}$ for 9 months, the other for 3 months. Reactions were carried out a total of five times by the same individual, and the scatterplot shows the calculated individual and median mRNA copy numbers (probe A: $5.6 \times 10^{7} \pm 1 \cdot 3 \times 10^{7}$; probe $B$ : $3.8 \times 10^{8} \pm 6 \cdot 2 \times 10^{7}$ copies $/ \mu \mathrm{g}$ total RNA).

normalisation to GAPDH may be valid (Edwards \& Denhardt 1985, Winer et al. 1999, Wall \& Edwards 2002), but for most experimental conditions its use is inappropriate and should be discontinued.

I have previously advocated normalisation to total cellular RNA as the least unreliable method (Bustin 2000). However, little is known about the total RNA content per cell of different tissues in vivo, or how this might vary between individuals or between normal and tumour tissue. We 
addressed a couple of these issues by taking blood samples from 62 healthy volunteers and counting and purifying the nucleated blood cells (NBCs). Total RNA was prepared using Qiagen's RNeasy RNA extraction kit and the RNA content was quantitated using a Pharmacia Genequant spectrophotometer. This revealed relatively little variation in the amount of total RNA per cell, with a median of $2 \cdot 1 \mathrm{ng} /$ cell (range $0 \cdot 36-2 \cdot 8 \mathrm{ng}$ ), which translates into $8.5 \times 10^{5} \mathrm{NBC} / \mu \mathrm{g}$ total RNA (range $\left.4.3 \times 10^{5}-2 \cdot 8 \times 10^{6}\right)$. This analysis is more difficult to make when analysing solid tissue, but it does confirm the validity of normalising to total RNA when comparing results between individuals.

Normalisation to total RNA content requires accurate quantification of the RNA sample and two methods are commonly used. First, the RiboGreen RNA quantification assay (www.probes.com) relies on a proprietary dye that exhibits significant fluorescence enhancement on binding to nucleic acids and can be detected in a spectrofluorometer, fluorescence microplate reader or filter-based fluorometer (Jones et al. 1998). The more traditional method uses absorbance measures at $\mathrm{OD}_{260}$ in a spectrophotometer. Since it is generally assumed that $\mathrm{OD}_{260}$ analysis is less accurate than the RiboGreen assay, we have compared RNA quantification data obtained using the RiboGreen assay with $\mathrm{OD}_{260}$ analysis using a Genequant II (Pharmacia). The results (Fig. 5) suggest that both methods generate comparable results when the RNA concentration is not less than $100 \mathrm{ng} / \mu \mathrm{l}$, with RiboGreen measurements lower than those obtained using the spectrophotometer. $\mathrm{OD}_{260}$ analysis becomes less reliable at lower RNA concentrations. Neither of the two methods provides reliable information about the quality of the RNA, a key consideration when quantitating mRNA levels in fresh tissue. Therefore, both methodologies are likely to be superseded by the recent introduction of the RNA 6000 LabChip, which allows the use of a Bioanalyser such as the Agilent 2100 (www.agilent.com) to integrate the quantification of RNA samples with a quality assessment in one rapid step. This is particularly important when the RNA has been extracted from 'dirty' tissue such as the colon and we now routinely subject all our RNA to this analysis.

An important consideration when using total RNA for normalisation is the lack of internal control for RT or PGR inhibitors. All quantitative methods

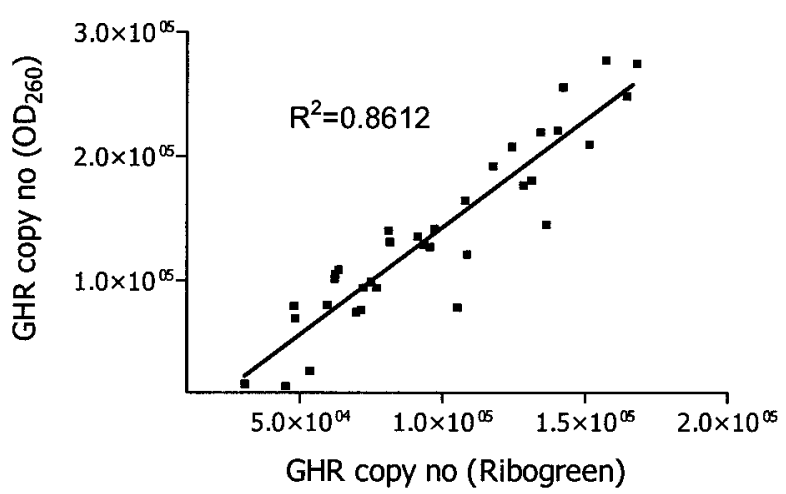

Figure 5. Comparison of RNA quantification using the Genequant II and the RiboGreen fluorescent assay. RNA from 34 normal colon biopsies was quantitated using a standard Genequant II protocol which measures the absorbance at $260 \mathrm{~nm}$. The same samples were then quantitated using a standard RiboGreen fluorescent assay. RT-PCR assays targeting the GHR were carried out and $C_{\mathrm{t}}$ normalised against the respective concentrations determined by the two methods. The scatterplot shows a good correlation between the two methods $\left(r^{2}=0 \cdot 8612\right)$.

assume that the RNA targets are reverse transcribed and subsequently amplified with similar efficiency. The risk with normalisation against external standards is that a proportion of the samples might contain some inhibitor that significantly reduces the efficiency of the RT-PCR reaction, resulting in inaccurate quantification. Therefore, it is necessary to develop universal internal standards that can be added to the RNA preparation to monitor the efficiency of $\mathrm{RT}$ reaction.

A major problem arises when RNA is prepared from extremely small samples, i.e. from LCM. Here it is not possible to quantitate the RNA sample, and it becomes necessary to normalise copy number to some internal RNA template. When dealing with in vivo samples it is not possible to predict which housekeeping gene might be useful, indeed it is likely that mRNA levels of all housekeeping genes vary to such degree that normalisation becomes inaccurate and/or misleading. rRNA, which makes up the bulk of a total RNA sample, has been proposed as an alternative normaliser (Bhatia et al. 1994, Zhong \& Simons 1999), despite reservations concerning its expression levels, transcription by a different RNA polymerase and possible imbalances in rRNA and mRNA fractions between different samples (Solanas et al. 2001). Its use has been validated 
recently by a study that showed its levels remaining constant during serum-stimulation of tissue culture cells (Schmittgen \& Zakrajsek 2000), a conclusion supported by another recent study (Goidin et al. 2001). If a researcher insists on normalising mRNA levels in tissue culture cells to a housekeeping gene, there is an endogenous control plate available for Taqman assays from ABI that evaluates the expression of 11 housekeeping genes (http://docs. appliedbiosystems.com/pebiodocs/04308134.pdf).

\section{Conclusions}

The comparative ease and rapidity with which quantitative data can be acquired using real-time RT-PCR assays has generated the impression that those data are reliable and can be subjected to objective statistical analysis. In reality, it is very difficult to answer the question of how quantitative, reproducible or informative real-time RT-PCR is. Deceptively easy techniques such as real-time RT-PCR create bandwagon effects, and results are generated with little understanding of the subtleties involved and with the statistical analyses of the numerical data obscuring and allowing misinterpretation of the actual results. The wide range of enzymes, unlimited number of different primer, probe and amplicon combinations, the fact that very few in vivo data have been obtained from clearly defined cell samples contribute to a general feeling of unease when confronted with quantitative RT-PGR data. The reluctance of many authors to describe comprehensively their protocols, the absence of acceptable validation of normalisation procedures between samples, and the difficulties in reproducing data reported in one laboratory by another one raises serious questions concerning the validity of many interpretations of data. Coupled with this, there is an inordinate divergence in standards applied by reviewers, resulting in the publication of scientific papers where, upon close inspection, the data do not actually support the authors' conclusions. Today's challenge is no longer the need to develop ever more sensitive and specific quantification assays but to advance experimental protocols and designs that are rigorously controlled and allow meaningful global comparisons.

Therefore, I would like to recommend for discussion several points that should help towards making real-time RT-PCR a meaningful means of quantitating mRNA expression profiles:

1. Strict validation of any reagent is required. The quality and quantity of RNA templates must be closely monitored and reported when publishing.

2. There must be standardisation of methodology for relatable comparison between laboratories. A lead by a commercial company, along the lines the StaRT approach, could result in universal protocols and reagents.

3. Standard internal controls must be included to monitor RT and PGR efficiencies and results must be published.

4. Every qRT-PCR run should include an amplicon-specific standard curve generated by serial dilution of a sense strand oligonucleotide. This may prove to be limiting when attempting to profile numerous genes simultaneously and will add significantly to the cost of the assay. It may be possible to use a strictly controlled reference mRNA, cDNA preparation or mixture of amplicons, but again it must be commercial companies providing these reagents.

5. Reactions should be set up using robots to ensure minimal variability, and a consensus with regard to intra-sample variability must be established.

6. Normalisation of samples obtained from in vitro experiments can be carried out against a panel (probably two or three) of housekeeping genes whose expression has been shown to be unaffected by experimental conditions. This information must be included in any publication. However, normalisation against cell number, total RNA or rRNA is preferable.

7. Normalisation of samples obtained in vivo must be carried out against cell number (if nucleated blood cells), rRNA or total RNA. There is no justification or reason for using housekeeping genes.

8. Any conclusions from experiments involving in vivo tissue samples are hindered by the heterogeneity of material, especially so when using tumour samples. The use of additional techniques, such as LCM, to enrich for individual cell types or cell location should become mandatory as it is crucial for relevant data interpretation.

Finally, it must be remembered that real-time RT-PCR quantitates steady state mRNA levels and no more. Accurate quantification of mRNA levels 
tells the researcher nothing about either transcription levels or mRNA stability. RNA levels may not reflect the levels of protein produced by the cell (Gygi et al. 1999), as for many regulation occurs at the post-transcriptional stage. RT-PCR data are totally uninformative about protein activity, or about any possible mutation that the target gene might harbour. Complete and biologically relevant analysis of gene expression requires additional information, especially that derived from immunohistochemistry and biochemical assays.

\section{Acknowledgements}

I gratefully acknowledge support from Bowel Cancer Research and the Joint Research Board of St Bartholomew's Hospital. I would like to thank Qiagen for their gift of Sensiscript, Biosearch for their gift of IGF-II probes, Adrian Palmer (Roche) for carrying out the extraction of RNA on the Magnapure and the RT-PCR on the Lightcycler and Jane Theaker and Stephen Little for additional information on Scorpions.

\section{References}

Afonina I, Kutyavin I, Lukhtanov E, Meyer RB \& Gamper H 1996 Sequence-specific arrest of primer extension on single-stranded DNA by an oligonucleotide-minor groove binder conjugate. PNAS 93 3199-3204.

Battaglia M, Pedrazzoli P, Palermo B, Lanza A, Bertolini F, Gibelli N, Da Prada GA, Zambelli A, Perotti C \& Robustelli della Cuna G 1998 Epithelial tumour cell detection and the unsolved problems of nested RT-PCR: a new sensitive one step method without false positive results. Bone Marrow Transplantation 22 693-698.

Bhatia P, Taylor WR, Greenberg AH \& Wright JA 1994 Comparison of glyceraldehyde-3-phosphate dehydrogenase and 28S-ribosomal RNA gene expression as RNA loading controls for northern blot analysis of cell lines of varying malignant potential. Analytical Biochemistry 216 223-226.

Bieche I, Onody P, Laurendeau I, Olivi M, Vidaud D, Lidereau R \& Vidaud M 1999 Real-time reverse transcription-PGR assay for future management of ERBB2-based clinical applications. Clinical Chemistry 45 1 1 148-1 156.

Bijwaard KE, Aguilera NS, Monczak Y, Trudel M, Taubenberger JK \& Lichy JH 2001 Quantitative real-time reverse transcriptionPCR assay for cyclin D1 expression: utility in the diagnosis of mantle cell lymphoma. Clinical Chemistry 47 195-201.

Bock O, Kreipe H \& Lehmann U 2001 One-step extraction of RNA from archival biopsies. Analytical Biochemistry 295 116-117.

Bohle RM, Hartmann E, Kinfe T, Ermert L, Seeger W \& Fink L 2000 Cell type-specific mRNA quantitation in non-neoplastic tissues after laser-assisted cell picking. Pathobiology 68 191-195.

Bolufer P, Lo CF, Grimwade D, Barragan E, Diverio D, Cassinat B, Chomienne C, Gonzalez M, Colomer D, Gomez MT, Marugan I, Roman J, Delgado MD, Garcia-Marco JA, Bornstein R,
Vizmanos JL, Martinez B, Jansen J, Villegas A, de Blas JM, Cabello P \& Sanz MA 2001 Variability in the levels of PML-RARa fusion transcripts detected by the laboratories participating in an external quality control program using several reverse transcription polymerase chain reaction protocols. Haematologica $86570-576$.

Buonamici S, Ottaviani E, Testoni N, Montefusco V, Visani G, Bonifazi F, Amabile M, Terragna C, Ruggeri D, Piccaluga PP, Isidori A, Malagola M, Baccarani M, Tura S \& Martinelli G 2002 Real-time quantitation of minimal residual disease in inv(16)-positive acute myeloid leukemia may indicate risk for clinical relapse and may identify patients in a curable state. Blood $99443-449$

Bustin SA 2000 Absolute quantification of mRNA using real-time reverse transcription polymerase chain reaction assays. Fournal of Molecular Endocrinology 25 169-193.

Bustin SA \& Dorudi S 1998 Molecular assessment of tumour stage and disease recurrence using PCR-based assays. Molecular Medicine Today 4 389-396.

Bustin SA, Gyselman VG, Williams NS \& Dorudi S 1999 Detection of cytokeratins 19/20 and guanylyl cyclase C in peripheral blood of colorectal cancer patients. British Fournal of Cancer $\mathbf{7 9}$ 1813-1820.

Bustin SA, Gyselman VG, Siddiqi S \& Dorudi S 2000 Cytokeratin 20 is not a tissue-specific marker for the detection of malignant epithelial cells in the blood of colorectal cancer patients. International Foumal Surgical Investigation 2 49-57.

Bustin SA, Li SR, Phillips S \& Dorudi S 2001 Expression of HLA class II in colorectal cancer: evidence for enhanced immunogenicity of microsatellite-instability-positive tumours. Tumor Biology 22 294-298.

Calogero A, Timmer-Bosscha H, Schraffordt KH, Tiebosch AT, Mulder NH \& Hospers GA 2000 Limitations of the nested reverse transcriptase polymerase chain reaction on tyrosinase for the detection of malignant melanoma micrometastases in lymph nodes. British Fournal of Cancer 83 184-187.

Chelly J, Concordet JP, Kaplan JC \& Kahn A 1989 Illegitimate transcription: transcription of any gene in any cell type. PNAS $\mathbf{8 6}$ 2617-2621.

Cheung IY \& Cheung NK 2001 Quantitation of marrow disease in neuroblastoma by real-time reverse transcription-PCR. Clinical Cancer Research 7 1698-1705.

Chou Q, Russell M, Birch DE, Raymond J \& Bloch W 1992 Prevention of pre-PCR mis-priming and primer dimerization improves low-copy-number amplifications. Nucleic Acids Research 20 $1717-1723$.

Cohen CD, Frach K, Schlondorff D \& Kretzler M 2002a Quantitative gene expression analysis in renal biopsies: a novel protocol for a high-throughput multicenter application. Kidney International 61 133-140.

Cohen CD, Grone HJ, Grone EF, Nelson PJ, Schlondorff D \& Kretzler M $2002 b$ Laser microdissection and gene expression analysis on formaldehyde-fixed archival tissue. Kidney International 61 125-132.

Crawford EL, Peters GJ, Noordhuis P, Rots MG, Vondracek M, Grafstrom RC, Lieuallen K, Lennon G, Zahorchak RJ, Georgeson MJ, Wali A, Lechner JF, Fan PS, Kahaleh MB, Khuder SA, Warner KA, Weaver DA \& Willey JC 2001 Reproducible gene expression measurement among multiple laboratories obtained in a blinded study using standardized RT (StaRT)-PCR. Molecular Diagnostics 6 217-225.

DeMuth JP, Jackson CM, Weaver DA, Crawford EL, Durzinsky DS, Durham SJ, Zaher A, Phillips ER, Khuder SA \& Willey JC 1998 The gene expression index c-myc x E2F-1/p21 is highly predictive of malignant phenotype in human bronchial epithelial cells. American Journal of Respiratory Cell and Molecular Biology 19 $18-24$. 
Deng G, Lu Y, Zlotnikov G, Thor AD \& Smith HS 1996 Loss of heterozygosity in normal tissue adjacent to breast carcinomas. Science 274 2057-2059.

Dolter KE \& Braman JC 2001 Small-sample total RNA purification: laser capture microdissection and cultured cell applications. Biotechniques 30 1358-1361.

Edwards DR \& Denhardt DT 1985 A study of mitochondrial and nuclear transcription with cloned cDNA probes. Changes in the relative abundance of mitochondrial transcripts after stimulation of quiescent mouse fibroblasts. Experimental Cell Research $\mathbf{1 5 7}$ $127-143$.

Egholm M, Buchardt O, Christensen L, Behrens C, Freier SM, Driver DA, Berg RH, Kim SK, Norden B \& Nielsen PE 1993 PNA hybridizes to complementary oligonucleotides obeying the Watson-Crick hydrogen-bonding rules. Nature 365 566-568.

Eis PS, Olson MC, Takova T, Curtis ML, Olson SM, Vener TI, Ip HS, Vedvik KL, Bartholomay CT, Allawi HT, Ma WP, Hall JG, Morin MD, Rushmore TH, Lyamichev VI \& Kwiatkowski RW 2001 An invasive cleavage assay for direct quantitation of specific RNAs. Nature Biotechnology 19 673-676.

Emmert-Buck MR, Bonner RF, Smith PD, Chuaqui RF, Zhuang Z, Goldstein SR, Weiss RA \& Liotta LA 1996 Laser capture microdissection. Science 274 998-1001.

Fiandaca MJ, Hyldig-Nielsen JJ, Gildea BD \& Coull JM 2001 Self-reporting PNA/DNA primers for PCR analysis. Genome Research 11 609-613.

Fink L, Kinfe T, Stein MM, Ermert L, Hanze J, Kummer W, Seeger W \& Bohle RM 2000 Immunostaining and laser-assisted cell picking for mRNA analysis. Laboratory Investigations $\mathbf{8 0}$ 327-333.

Fink L, Kohlhoff S, Stein MM, Hanze J, Weissmann N, Rose F, Akkayagil E, Manz D, Grimminger F, Seeger W \& Bohle RM 2002 cDNA array hybridization after laser-assisted microdissection from nonneoplastic tissue. American Fournal of Pathology 160 81-90.

Gelmini S, Tricarico C, Vona G, Livi L, Melina AD, Serni S, Cellai E, Magrini S, Villari D, Carini M, Serio M, Forti G, Pazzagli M \& Orlando C 2001 Real-time quantitative reverse transcriptasepolymerase chain reaction (RT-PCR) for the measurement of prostate-specific antigen $\mathrm{mRNA}$ in the peripheral blood of patients with prostate carcinoma using the taqman detection system. Clinical Chemistry and Laboratory Medicine 39 385-391.

Gilliland G, Perrin S, Blanchard K \& Bunn HF 1990 Analysis of cytokine mRNA and DNA: detection and quantitation by competitive polymerase chain reaction. PNAS 87 2725-2729.

Godfrey TE, Kim SH, Chavira M, Ruff DW, Warren RS, Gray JW \& Jensen RH 2000 Quantitative mRNA expression analysis from formalin-fixed, paraffin-embedded tissues using $5^{\prime}$ nuclease quantitative reverse transcription-polymerase chain reaction. Fournal of Molecular Diagnostics 2 84-91.

Goerke C, Bayer MG \& Wolz C 2001 Quantification of bacterial transcripts during infection using competitive reverse transcription-PCR (RT-PCR) and LightCycler RT-PCR. Clinical and Diagnostic Laboratory Immunology 8 279-282.

Goidin D, Mamessier A, Staquet MJ, Schmitt D \& Berthier-Vergnes O 2001 Ribosomal 18S RNA prevails over glyceraldehyde-3phosphate dehydrogenase and beta-actin genes as internal standard for quantitative comparison of mRNA levels in invasive and noninvasive human melanoma cell subpopulations. Analytical Biochemistry 295 17-21.

Goldsworthy SM, Stockton PS, Trempus CS, Foley JF \& Maronpot RR 1999 Effects of fixation on RNA extraction and amplification from laser capture microdissected tissue. Molecular Carcinogenesis 25 86-91.

Greijer AE, Adriaanse HM, Dekkers CA \& Middeldorp JM 2002 Multiplex real-time NASBA for monitoring expression dynamics of human cytomegalovirus encoded IE1 and pp67 RNA. Fournal of Clinical Virology 24 57-66.
Gygi SP, Rochon Y, Franza BR \& Aebersold R 1999 Correlation between protein and mRNA abundance in yeast. Molecular and Cell Biology 19 1720-1730.

Halford WP, Falco VC, Gebhardt BM \& Carr DJ 1999 The inherent quantitative capacity of the reverse transcriptionpolymerase chain reaction. Analytical Biochemistry 266 181-191.

Hall JG, Eis PS, Law SM, Reynaldo LP, Prudent JR, Marshall DJ, Allawi HT, Mast AL, Dahlberg JE, Kwiatkowski RW, de Arruda M, Neri BP \& Lyamichev VI 2000 Sensitive detection of DNA polymorphisms by the serial invasive signal amplification reaction. PNAS 97 8272-8277.

Harrington JJ \& Lieber MR 1994 Functional domains within FEN-1 and RAD2 define a family of structure-specific endonucleases: implications for nucleotide excision repair. Genes and Development $\mathbf{8}$ 1344-1355.

Heid CA, Stevens J, Livak KJ \& Williams PM 1996 Real time quantitative PCR. Genome Research 6 986-994.

Hein I, Lehner A, Rieck P, Klein K, Brandl E \& Wagner M 2001 Comparison of different approaches to quantify Staphylococcus aureus cells by real-time quantitative PCR and application of this technique for examination of cheese. Applied Environmental Microbiology 67 3122-3126.

Hempel DM, Smith KA, Claussen KA \& Perricone MA 2002 Analysis of cellular immune responses in the peripheral blood of mice using real-time RT-PCR. Fournal of Immunological Methods 259 129-138.

Jones LJ, Yue ST, Cheung CY \& Singer VL 1998 RNA quantitation by fluorescence-based solution assay: RiboGreen reagent characterization. Analytical Biochemistry 265 368-374.

Ke LD, Chen Z \& Yung WK 2000 A reliability test of standard-based quantitative PCR: exogenous vs endogenous standards. Molecular and Cellular Probes 14 127-135.

Kebelmann-Betzing C, Seeger K, Dragon S, Schmitt G, Moricke A, Schild TA, Henze G \& Beyermann B 1998 Advantages of a new Taq DNA polymerase in multiplex PCR and time-release PCR. Biotechniques 24 154-158.

Klimecki WT, Futscher BW \& Dalton WS 1994 Effects of ethanol and paraformaldehyde on RNA yield and quality. Biotechniques $\mathbf{1 6}$ $1021-1023$

Kumar S, Reed MW, Gamper HB, Jr, Gorn VV, Lukhtanov EA, Foti M, West J, Meyer RB, Jr \& Schweitzer BI 1998 Solution structure of a highly stable DNA duplex conjugated to a minor groove binder. Nucleic Acids Research 26 831-838.

Kutyavin IV, Afonina IA, Mills A, Gorn VV, Lukhtanov EA, Belousov ES, Singer MJ, Walburger DK, Lokhov SG, Gall AA, Dempcy R, Reed MW, Meyer RB \& Hedgpeth J 2000 3'-minor groove binder-DNA probes increase sequence specificity at PCR extension temperatures. Nucleic Acids Research 28 655-661.

Lehmann U, Bock O, Glockner S \& Kreipe H 2000 Quantitative molecular analysis of laser-microdissected paraffin-embedded human tissues. Pathobiology 68 202-208.

Li SR, Dorudi S \& Bustin SA 2000 Elevated levels of RanBP7 mRNA in colorectal carcinoma are associated with increased proliferation and are similar to the transcription pattern of the proto-oncogene c-myc. Biochemical and Biophysical Research Communications $271322-329$.

Liu J, Feldman P \& Chung TD 2002 Real-time monitoring in vitro transcription using molecular beacons. Analytical Biochemistry $\mathbf{3 0 0}$ $40-45$.

Lyamichev V, Mast AL, Hall JG, Prudent JR, Kaiser MW, Takova T, Kwiatkowski RW, Sander TJ, de Arruda M, Arco DA, Neri BP \& Brow MA 1999 Polymorphism identification and quantitative detection of genomic DNA by invasive cleavage of oligonucleotide probes. Nature Biotechnology 17 292-296.

Malboeuf CM, Isaacs SJ, Tran NH \& Kim B 2001 Thermal effects on reverse transcription: improvement of accuracy and processivity in cDNA synthesis. Biotechniques $\mathbf{3 0} 1074$. 
Masuda N, Ohnishi T, Kawamoto S, Monden M \& Okubo K 1999 Analysis of chemical modification of RNA from formalin-fixed samples and optimization of molecular biology applications for such samples. Nucleic Acids Research 27 4436-4443.

Mifflin TE, Estey CA \& Felder RA 2000 Robotic automation performs a nested RT-PCR analysis for HCV without introducing sample contamination. Clinica Chimica Acta 290 199-211.

Miyoshi Y, Ando A, Takamura Y, Taguchi T, Tamaki Y \& Noguchi S 2002 Prediction of response to docetaxel by CYP3A4 mRNA expression in breast cancer tissues. International Journal of Cancer $\mathbf{9 7}$ $129-132$

Mizuno T, Nagamura H, Iwamoto KS, Ito T, Fukuhara T, Tokunaga M, Tokuoka S, Mabuchi K \& Seyama T 1998 RNA from decades-old archival tissue blocks for retrospective studies. Diagnostic Molecular Pathology 7 202-208.

Nielsen PE, Egholm M, Berg RH \& Buchardt O 1991 Sequence-selective recognition of DNA by strand displacement with a thymine-substituted polyamide. Science 254 1497-1500.

Orlando C, Pinzani P \& Pazzagli M 1998 Developments in quantitative PCR. Clinical Chemistry Laboratory Medicine 36 255-269.

Ortiz E, Estrada G \& Lizardi PM 1998 PNA molecular beacons for rapid detection of PCR amplicons. Molecular and Cellular Probes 12 219-226.

Orum H, Nielsen PE, Egholm M, Berg RH, Buchardt O \& Stanley C 1993 Single base pair mutation analysis by PNA directed PCR clamping. Nucleic Acids Research 21 5332-5336.

Parlato R, Rosica A, Cuccurullo V, Mansi L, Macchia P, Owens JD, Mushinski JF, De Felice M, Bonner RF \& Di Lauro R 2002 A preservation method that allows recovery of intact RNA from tissues dissected by laser capture microdissection. Analytical Biochemistry 300 139-145.

Raja S, Luketich JD, Kelly LA, Ruff DW \& Godfrey TE 2000 Increased sensitivity of one-tube, quantitative RT-PCR. Biotechniques 29702.

Reinhold U, Berkin C, Bosserhoff AK, Deutschmann A, Garbe C, Glaser R, Hein R, Krahn G, Peter RU, Rappl G, Schittek B, Seiter S, Ugurel S, Volkenandt M \& Tilgen W 2001 Interlaboratory evaluation of a new reverse transcriptase polymerase chain reaction-based enzyme-linked immunosorbent assay for the detection of circulating melanoma cells: a multicenter study of the Dermatologic Cooperative Oncology Group. Fournal of Clinical Oncology 19 1723-1727.

Rupp GM \& Locker J 1988 Purification and analysis of RNA from paraffin-embedded tissues. Biotechniques 6 56-60.

Schmittgen TD \& Zakrajsek BA 2000 Effect of experimental treatment on housekeeping gene expression: validation by real-time, quantitative RT-PCR. Fournal of Biochemical and Biophysical Methods 46 69-81.

Schweitzer B \& Kingsmore S 2001 Combining nucleic acid amplification and detection. Current Opinions in Biotechnology 12 21-27.

Sirover MA 1999 New insights into an old protein: the functional diversity of mammalian glyceraldehyde-3-phosphate dehydrogenase. Biochimica et Biophysica Acta 1432 159-184.

Solanas M, Moral R \& Escrich E 2001 Unsuitability of using ribosomal RNA as loading control for Northern blot analyses related to the imbalance between messenger and ribosomal RNA content in rat mammary tumors. Analytical Biochemistry $\mathbf{2 8 8}$ 99-102.

Specht K, Richter T, Muller U, Walch A, Werner M \& Hofler H 2001 Quantitative gene expression analysis in microdissected archival formalin-fixed and paraffin-embedded tumor tissue. American Fournal of Pathology 158 419-429.

Stender H, Fiandaca M, Hyldig-Nielsen JJ \& Coull J 2002 PNA for rapid microbiology. Fournal of Microbiological Methods 48 1-17.

Stordeur P, Poulin LF, Craciun L, Zhou L, Schandene L, de Lavareille A, Goriely S \& Goldman M 2002 Cytokine mRNA quantification by real-time PCR. Fournal of Immunological Methods 259 55-64.

Sugita M, Haney JL, Gemmill RM \& Franklin WA 2001 One-step duplex reverse transcription-polymerase chain reaction for quantitative assessment of RNA degradation. Analytical Biochemistry $295113-116$.

Sugiyama Y, Sugiyama K, Hirai Y, Akiyama F \& Hasumi K 2002 Microdissection is essential for gene expression profiling of clinically resected cancer tissues. American Fournal of Clinical Pathology $117109-116$

Suzuki T, Higgins PJ \& Crawford DR 2000 Control selection for RNA quantitation. Biotechniques 29 332-337.

Swift GH, Peyton MJ \& MacDonald RJ 2000 Assessment of RNA quality by semi-quantitative RT-PCR of multiple regions of a long ubiquitous mRNA. Biotechniques 28 524-531.

Tatton WG, Chalmers-Redman RM, Elstner M, Leesch W, Jagodzinski FB, Stupak DP, Sugrue MM \& Tatton NA 2000 Glyceraldehyde-3-phosphate dehydrogenase in neurodegeneration and apoptosis signaling. Fournal of Neural Transmission. Supplementum $6077-100$.

Thelwell N, Millington S, Solinas A, Booth J \& Brown T 2000 Mode of action and application of Scorpion primers to mutation detection. Nucleic Acids Research 28 3752-3761.

Vu HL, Troubetzkoy S, Nguyen HH, Russell MW \& Mestecky J 2000 A method for quantification of absolute amounts of nucleic acids by (RT)-PGR and a new mathematical model for data analysis. Nucleic Acids Research $\mathbf{2 8}$ E18.

Walburger DK, Afonina IA \& Wydro R 2001 An improved real time PCR method for simultaneous detection of C282Y and H63D mutations in the HFE gene associated with hereditary hemochromatosis. Mutation Research 432 69-78.

Walch A, Specht K, Smida J, Aubele M, Zitzelsberger H, Hofler H \& Werner M 2001 Tissue microdissection techniques in quantitative genome and gene expression analyses. Histochemistry and Cell Biology 115 269-276.

Wall SJ \& Edwards DR 2002 Quantitative reverse transcriptionpolymerase chain reaction (RT-PCR): a comparison of primerdropping, competitive, and real-time RT-PCRs. Analytical Biochemistry 300 269-273.

Whitcombe D, Theaker J, Guy SP, Brown T \& Little S 1999 Detection of PCR products using self-probing amplicons and fluorescence. Nature Biotechnology 17 804-807.

Willey JC, Crawford EL, Jackson CM, Weaver DA, Hoban JC, Khuder SA \& DeMuth JP 1998 Expression measurement of many genes simultaneously by quantitative RT-PCR using standardized mixtures of competitive templates. American Fournal of Respiratory Cell and Molecular Biology 19 6-17.

Winer J, Jung CK, Shackel I \& Williams PM 1999 Development and validation of real-time quantitative reverse transcriptasepolymerase chain reaction for monitoring gene expression in cardiac myocytes in vitro. Analytical Biochemistry 270 41-49.

Yuen T, Zhang W, Ebersole BJ \& Sealfon SC 2002 Monitoring G-protein-coupled receptor signaling with DNA microarrays and real-time polymerase chain reaction. Methods in Enzymology 345 $556-569$.

Zhong H \& Simons JW 1999 Direct comparison of GAPDH, beta-actin, cyclophilin, and 28S rRNA as internal standards for quantifying RNA levels under hypoxia. Biochemical and Biophysical Research Communications 259 523-526.

Zhu G, Chang Y, Zuo J, Dong X, Zhang M, Hu G \& Fang F 2001 Fudenine, a C-terminal truncated rat homologue of mouse prominin, is blood glucose-regulated and can up-regulate the expression of GAPDH. Biochemical and Biophysical Research Communications 281 951-956.

Received 11 October 2001

Accepted 25 January 2002 